\title{
Sistem Informasi Absensi Pegawai Menggunakan Metode RAD dan Metode LBS Pada Koordinat Absensi
}

\author{
Mohammad Arya Rosyd Sikumbang ${ }^{1}$, Roni Habibi ${ }^{2}$, Syafrial Fachri Pane ${ }^{3}$ \\ ${ }^{1}$ D4 Teknik Informatika, Politeknik Pos Indonesia, Bandung, Indonesia \\ ${ }^{2}$ Program Studi Magister Informatika, Institut Teknologi Bandung, Bandung, Indonesia \\ ${ }^{3}$ Program Studi Magister Teknik Informatika, Bina Nusantara Jakarta, Jakarta, Indonesia \\ Email: ${ }^{1}$ arya.mohammad00@gmail.com, ${ }^{2}$ ronihabibi@poltekpos.ac.id, ${ }^{3}$ syafrial.fachri@poltekpos.ac.id
}

\begin{abstract}
Abstrak-Absensi dapat dikatakan suatu pendataan kehadiran yang merupakan bagian dari aktifitas pelaporan yang ada dalam sebuah institusi. Dalam sebuah perusahaan memerlukan kebijakan terutama tingkat kedisplinan pegawai. Kedisiplinan dari pegawai merupakan tolak ukur utama dalam melihat kinerja pegawai berdasarkan kehadirannya di perusahaan. Sebuah perusahaan harus memiliki sistem absensi kehadiran pegawai yang dapat mengatur kehadiran pegawai berdasarkan kewajiban, larangan, dan sanksi apabila kewajiban seorang pegawai tidak ditaati atau dilanggar. Permasalahan yang sering terjadi di Badan Pusat Statistika Kota Bandung adalah saat pegawai ditugaskan untuk melakukan perjalanan dinas sering kali pegawai tersebut tidak melakukan absensi terlebih dahulu ke kantor. Dengan menerapkan metode Rapid Application Development (RAD) merupakan suatu metode pengembangan perangkat lunak dengan pendekatan berorientasi objek (object oriented approach) terhadap pengembangan sistem. Metode ini bertujuan untuk mempersingkat waktu dalam perencanaan, perancangan, dan penerapan suatu sistem bila dibandingkan dengan metode tradisional. Lalu metode Location Based Service (LBS) digunakan untuk mengakses layanan informasi geografis yang digunakan oleh user dengan perangkat telepon seluler melalui koneksi jaringan selular untuk memetakan lokasi untuk menentukan dimana lokasi keberadaannya. Dengan demikian, dengan adanya penelitian ini dapat membantu perusahaan dan pegawai dalam melakukan kinerjanya tanpa disusahkan oleh tekanan dan banyaknya beban kerja yang didapatkan oleh pegawai.
\end{abstract}

Kata Kunci: Absensi, Kedisiplinan, RAD, LBS, Lokasi

Abstract-Attendance can be said to be a presence data collection that is part of reporting activities that exist within an institution. A company requires a policy, especially the level of employee discipline. Discipline from employees is the main benchmark in seeing employee performance based on his presence in the company. A company must have a staff attendance system that can manage employee attendance based on obligations, prohibitions, and sanctions if an employee's obligations are not obeyed or violated. The problem that often occurs at the Bandung Central Statistics Agency is when employees are assigned to take a business trip, often the employee does not attend first to the office. By applying the Rapid Application Development (RAD) method, a method of software development with an object-oriented approach to system development, this method shorten the time in planning, designing, and implementing a system compared to traditional methods. Then the Location Based Service (LBS) method is used to access geographical information services used by users with mobile phone devices through cellular network connections to map locations to determine where the location of the user is. Thus, the existence of this research can help companies and employees in performing their performance without being bothered by pressure of workload.

Keywords: Attendance, Discipline, RAD, LBS, Location

\section{PENDAHULUAN}

Teknologi informasi memiliki kemajuan yang sangat pesat sehingga menuntut semua orang maupun perusahaan untuk mengembangkan ilmu demi mempermudah kinerjanya. Dalam meningkatkan kualitas kinerja pegawai pada perusahaan, sistem layanan kehadiran merupakan salah satu faktor yang dapat mendorong performa dan kualitas kinerja pegawai. Kinerja pegawai pada perusahaan dapat berlangsung dengan baik dan lancar dengan adanya sistem informasi absensi kehadiran pegawai di perusahaan[1].

Absensi dapat dikatakan suatu pendataan kehadiran yang merupakan bagian dari aktifitas pelaporan yang ada dalam sebuah institusi[2]. Kehadiran berkenaan dengan tanggung jawab pegawai saat bekerja, pegawai yang hadir tepat waktu dan tidak terlambat saat masuk kerja bisa dikatakan mempunyai sifat disiplin.

Dalam sebuah perusahaan memerlukan kebijakan terutama tingkat kedisplinan pegawai. Kedisiplinan dari pegawai merupakan tolak ukur utama dalam melihat kinerja pegawai berdasarkan kehadirannya di perusahaan[3]. Berdasarkan dari data absensi, maka sebuah perusahaan harus memiliki sistem absensi kehadiran pegawai yang dapat mengatur kehadiran pegawai berdasarkan kewajiban, larangan, dan sanksi apabila kewajiban seorang pegawai tidak ditaati atau dilanggar[4].

Dalam penelitian ini studi kasus yang diangkat sebagai bahan penelitian adalah Perusahaan Badan Pusat Statistik Kota Bandung yang beralamat di Jl. Jendral Gatot Subroto No. 93 Bandung, Jawa Barat. Pada perusahaan Badan Pusat Statistik Kota Bandung sudah menerapkan teknologi sistem absensi menggunakan teknologi fingerprint. Permasalahan yang sering terjadi di Badan Pusat Statistika Kota Bandung adalah saat pegawai ditugaskan untuk melakukan perjalanan dinas sering kali pegawai tersebut tidak melakukan absensi terlebih dahulu ke kantor. Dikarenakan banyaknya beban kerja yang diterima pegawai dari setiap divisi sehingga berpengaruh terhadap kinerja pegawai tersebut dalam aturan perusahaan. Akan tetapi dengan seringnya terjadi kesalahan tersebut membuat bagian administrasi kewalahan dikarenakan proses rekapitulasi data absensi pegawai yang dilakukan masih menggunakan sistem perhitungan secara manual dan sering terjadi kesalahan dalam proses perhitungan rekapitulasi data absensi pegawai[5]. 
Dengan menerapkan metode Rapid Application Development (RAD) pada pengembangan dari aplikasi sebelumnya diharapkan dapat membantu dalam proses penyelesaian aplikasi. RAD merupakan suatu metode pengembangan perangkat lunak dengan pendekatan berorientasi objek (object oriented approach) terhadap pengembangan sistem. Metode ini bertujuan untuk mempersingkat waktu dalam perencanaan, perancangan, dan penerapan suatu sistem bila dibandingkan dengan metode tradisional[6]. Lalu metode Location Based Service (LBS) digunakan untuk mengakses layanan informasi geografis yang digunakan oleh user dengan perangkat telepon seluler melalui koneksi jaringan selular untuk memetakan lokasi untuk menentukan dimana lokasi keberadaannya[7]. Adapun penelitian yang sudah dilakukan yang sudah membahas tentang pemanfaatan metode LBS yang akan dijadikan sebagai pedoman dalam pengembangan di penelitian ini, yaitu : Pembangunan Aplikasi Child Tracker Berbasis Assisted - Global Positioning System (A-GPS) Dengan Platform Android[8].

Dari permasalahan tersebut, untuk meminimalisir kemungkinan terjadinya kendala dalam proses absensi kehadiran pegawai maka akan dibangun sebuah pengembangan aplikasi sistem informasi absensi pegawai dengan menerapkan koordinat pada platform android.[4] Dengan pemanfaatan aplikasi ini, maka diharapkan dapat menambah pengetahuan dan wawasan pegawai dalam perkembangan ilmu pengetahuan dan pemanfaatan sistem informasi. Sehingga pegawai tidak perlu dipusingkan lagi untuk melakukan absensi terlebih dahulu ke kantor pada saat melakukan dinas dari kantor. Sehingga pegawai bisa melakukan pekerjaannya dan tidak mengganggu kinerja dari pegawai tersebut[9].

\section{METODE PENELITIAN}

\subsection{Absensi}

Absensi dapat dikatakan suatu pendataan kehadiran yang merupakan bagian dari aktifitas pelaporan yang ada dalam sebuah institusi[2]. Pada perusahaan Badan Pusat Statistik Kota Bandung menurut cara penggunaannya sudah menerapkan absensi non manual dengan menggunakan teknologi fingerprint yang digunakan untuk pencatatan kegiatan kehadiran pegawai dan dalam pengelolaan data absensinya menggunakan Microsoft Excel sebagai alat bantu dalam perhitungannya.

\subsection{Presensi}

Presensi pegawai adalah suatu kegiatan pencatatan terhadap setiap kehadiran pegawai dengan tujuan untuk mengetahui data yang berkaitan dengan kehadiran masuk dan keluar pegawai secara periodik baik harian maupun bulanan. Data presensi pegawai didapatkan dari penerapan teknologi fingerprint yang sudah diterapkan oleh perusahaan Badan Pusat Statistik Kota Bandung.

\subsection{Absen}

Absen adalah tidak bekerjanya seorang pegawai pada saat hari kerja[10]. Biasanya pegawai tidak dapat masuk dikarenakan beberapa macam hal diantaranya karena sakit, izin, alpa, atau cuti yang merupakan menjadi parameter dalam menentukan kedisiplinan pegawai di perusahaan Badan Pusat Statistik Kota Bandung. Akan tetapi, berdasarkan parameter dalam menentukan kedisiplinan pegawai tersebut kerja dinas kerap dijadikan menjadi alasan untuk melakukan absen pada perusahaan. Sehingga berpengaruh dalam penentuan kedisiplinan pegawai.

\subsection{RAD (Rapid Application Development)}

Rapid Application Development (RAD) adalah metode yang digunakan dalam pembuatan aplikasi absensi pegawai. Rapid Application Development (RAD) sebuah metode pengembangan sistem dengan pendekatan prototyping yang dirancang untuk menghasilkan sistem yang berkualitas tinggi dengan waktu yang relatif cepat serta biaya yang cukup rendah[4].

\subsection{LBS (Location Based Service)}

Location Based Service adalah layanan informasi yang dapat diakses melalui mobile device dengan menggunakan mobile network, yang dilengkapi kemampuan untuk memanfaatkan lokasi dari mobile device tersebut[7]. Dalam pemanfaatan layanan location based service untuk memperoleh posisi pengguna ada 2 tipe layanan yang bisa digunakan, yaitu menggunakan GPS atau A-GPS. Dari kedua layanan tersebut akan didapatkan posisi pengguna dalam bentuk koordinat longitude dan latitude. Location Based Service juga bisa dilihat dari sisi layanan yang diberikan, seperti Reactive Location Based Services dan Proactive Location Based Services.

Reactive Location Based Services adalah layanan yang hanya aktif jika ada aksi yang dilakukan pengguna. Sedangkan proactive location based services merupakan layanan yang akan selalu memberi informasi kepada pengguna walaupun pengguna tidak melakukan permintaan terhadap layanan[11]. Dalam penelitian ini layanan yang diterapkan dalam penggunaan \textit\{location based service\} adalah Itextit\{reactive location based services\}. Layanan berbasis lokasi terdiri dari 5 komponen utama yaitu :

1. Mobile devices, Suatu alat yang digunakan oleh pengguna untuk meminta informasi yang dibutuhkan.

2. Communication Network, Jaringan komunikasi yang mengirim data pengguna dan informasi yang diminta dari mobile terminal ke Service Provider kemudian mengirimkan kembali informasi yang diminta ke pengguna. 
Communication network dapat berupa jaringan seluler (GSM, CDMA), Wireless Local Area Network (WLAN), atau Wireless Wide Area Network (WWAN).

3. Positioning Component, Untuk memproses sesuatu dalam mengendalikan layanan maka posisi pengguna harus diketahui peta.

4. Service and Application Provider, Penyadia layanan menawarkan berbagai macam layanan kepada pengguna dan bertanggung jawab untuk memproses informasi yang diminta pengguna.

5. Data and Content Provider, Penyedia layanan tidak selalu menyimpan semua data yang dibutuhkan yang bisa diakses oleh pengguna. Untuk itu, data dapat diminta dari content provider. Komponen dasar LBS digambarkan seperti pada gambar berikut:

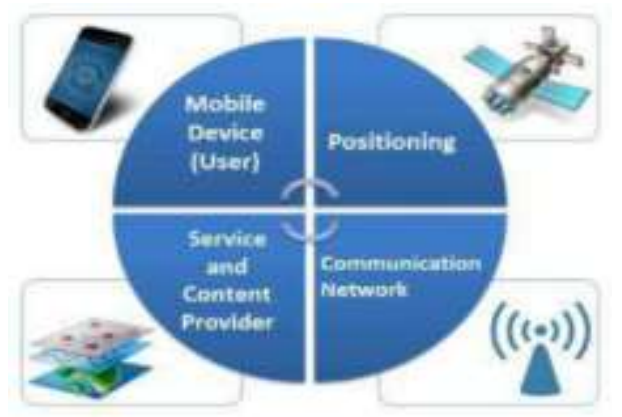

Gambar 1. Komponen Dasar Location Based Service

Teorema Haversine Formula adalah sebuah persamaan yang penting dalam bidang navigasi, untuk mencari jarak busur antara dua titik pada bola dari longitude dan latitude. Ini merupakan bentuk persamaan khusus dari trigonometri bola, law of haversines, mencari hubungan sisi dan sudut pada segitiga dalam bisang bola[11].

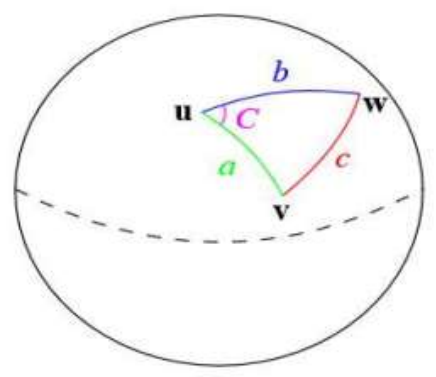

Gambar 2. Trigonometri Bola

$$
\text { jarak }=2 r \cdot \arcsin \sqrt{\sin \left(\frac{\text { lat } 1-\text { lat } 2}{2}\right)^{2}+\cos (\text { lat } 1) \cdot \cos (\text { lat } 2) \cdot \sin \left(\frac{\text { long } 1-\text { long } 2}{2}\right)^{2}}
$$

Dimana : $\quad$ jarak $=\mathrm{km}$

$$
\begin{aligned}
& 2 \mathrm{r}=\text { radius bumi }(6371 \mathrm{~km}) \\
& \text { Lat } 1=\text { latitude awal } \\
& \text { Lat2 = latitude akhir } \\
& \text { Long } 1=\text { longitude awal } \\
& \text { Long2 = longitude akhir }
\end{aligned}
$$

Rumus haversine digunakan untuk menghitung jarak lokasi tempat melakukan dinas luar pegawai dengan jarak kantor Badan Pusat Statistik Kota Bandung saat itu.

\section{HASIL DAN PEMBAHASAN}

\subsection{Analisis Yang Akan Dibangun}

Pada analisis prosedur yang akan dibangun pegawai yang akan melakukan presensi harus me-scan qr code yang dimilikinya pada sistem yang dibuat. Data hasil scan tersebut akan otomatis disimpan kedalam sistem. Lalu bagian tata usaha akan memonitoring data yang sudah tersimpan dan akan mengelola data tersebut sesuai dengan kebutuhan perusahaan. Setelah bagian tata usaha mengelola data presensi tersebut maka tahap akhir yang akan dilakukan adalah mencetak report absensi pegawai tersebut. 


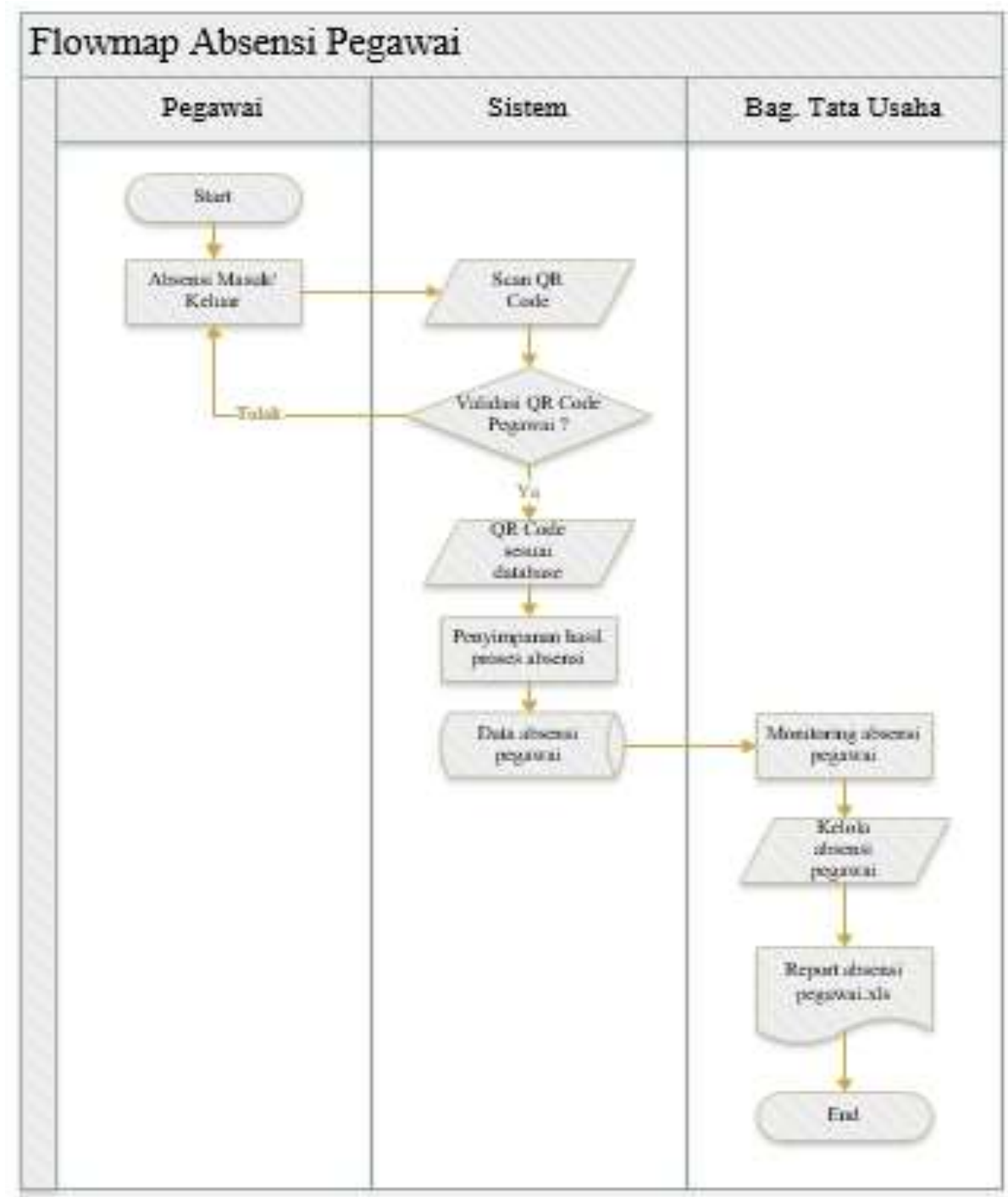

Gambar 3. Flowmap Analisis Yang Akan Dibangun

\subsection{UML (Unified Modeling Languange)}

Dalam perancangan pada laporan ini digunakan UML (Unified Modeling Languange) sebagai penggambaran, perencanaan, dan pembuatan sketsa atau pengaturan dari beberapa elemen yang terpisah ke dalam suatu kesatuan yang utuh.

Berdasarkan gambar dibawah yang merupakan gambaran dari Use Case Diagram sistem. Dimana terdapat 2 aktor dan 8 usecase diagram antara lain, usecase login, usecase master data, usecase dinas luar, usecase hari libur, usecase laporan, usecase pengaturan, usecase absensi, dan usecase cuti. Aktor bagian tata usaha dapat mengelola semua usecase sedangkan aktor pegawai hanya dapat mengelola usecase absensi dan usecase cuti.

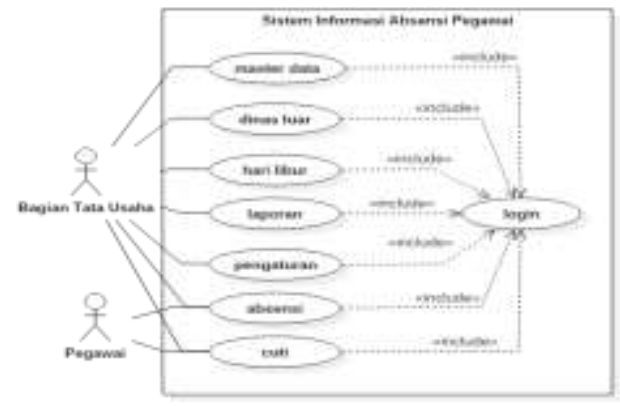

Gambar 4. Usecase Diagram 
Volume 4, Nomor 1, Januari 2020, Page 59-64

ISSN 2614-5278 (media cetak), ISSN 2548-8368 (media online)

Available Online at https://ejurnal.stmik-budidarma.ac.id/index.php/mib DOI $10.30865 /$ mib.v4i1.1445

\subsection{Implementasi}

Implementasi merupakan kelanjutan dari kegiatan perancangan aplikasi dan dapat dipandang sebagai usaha untuk mewujudkan aplikasi yang dirancang. Langkah-langkah dari proses implementasi adalah urutan dari kegiatan awal sampai kegiatan akhir yang harus dilakukan dalam mewujudkan sistem yang dirancang.

1. Tampilan Scanner QR Code

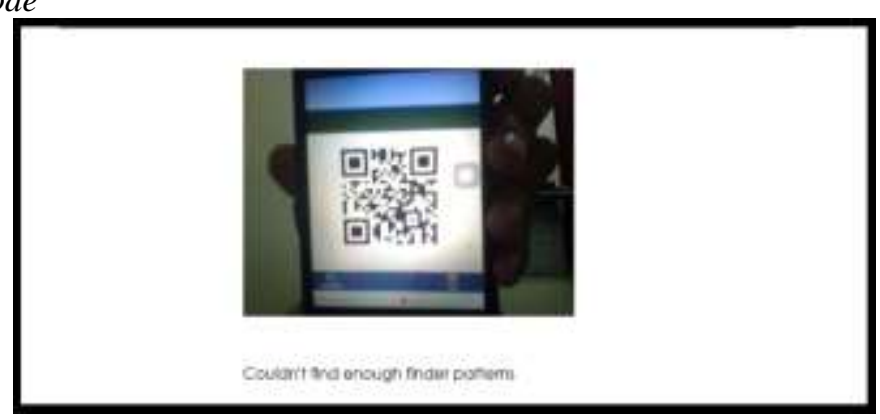

Gambar 5. Scanner $Q R$ Code

2. Tampilan Absen Dinas Luar

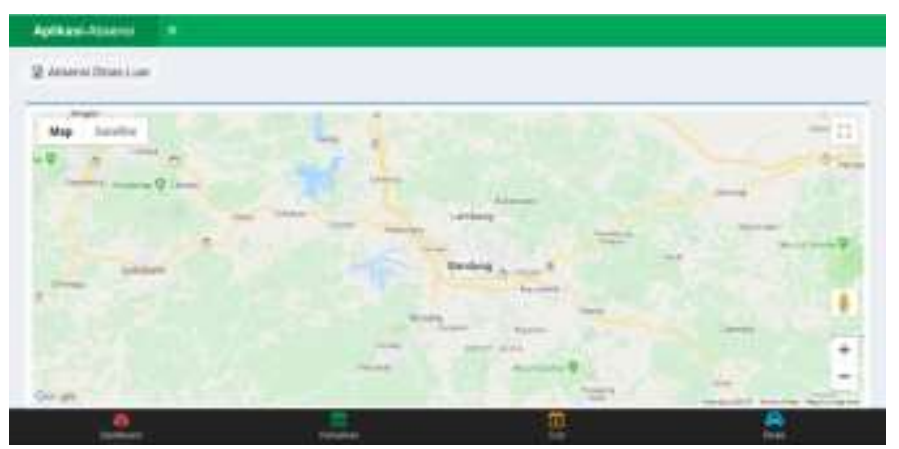

Gambar 6. Absen Dinas Luar

\subsection{Pengujian Black Box}

Tabel 1. Rencana Pengujian

\begin{tabular}{lll}
\hline Kelas Uji & Butir Uji & Jenis Pengujian \\
\hline Scan Qr Code & Verifikasi Qr Code & Black Box \\
Login & Verifikasi Username \& Password & Black Box \\
Master Data & Insert Master Data & Black Box \\
Absensi & Insert NIP Pegawai & Black Box \\
Cuti & Kelola Data Cuti Pegawai & Black Box \\
Cuti Pegawai & Insert Pengajuan Cuti & Black Box \\
Dinas Luar & Insert Data Dinas Luar Pegawai & Black Box \\
Dinas Luar Pegawai & Insert Absen Dinas Luar & Black Box \\
Hari Libur & Kelola Hari Libur Perusahaan & Black Box \\
Laporan & Kelola Laporan Absensi & Black Box \\
Pengaturan & Kelola Pengaturan Aplikasi Absensi & Black Box \\
Generate Qr Code & Generate Qr Code Pegawai & Black Box \\
\hline
\end{tabular}

Hasil dari perhitungan Teorema Haversine dengan menggunakan persamaan 1 dapat dilihat pada tabel 2 berikut ini:

Tabel 2. Pengujian Teorema Haversine

\begin{tabular}{llll}
\hline Tempat & Latitude & Longitude & Hasil \\
\cline { 1 - 2 } Kantor Utama & $-6,9236009$ & 107,6224521 & \\
Tempat 1 & $-6,9222775$ & 107,6216421 & 0,172189047 \\
Tempat 2 & $-6,9312612$ & 107,6179701 & 0,985040763 \\
Tempat 3 & $-6,9268542$ & 107,6362605 & 1,566561975 \\
Tempat 4 & $-6,9280956$ & 107,6184234 & 0,668990214 \\
Tempat 5 & $-6,9255708$ & 107,6301734 & 0,880003714 \\
\hline
\end{tabular}




\section{KESIMPULAN}

Dari masalah yang dipaparkan oleh penulis diatas, maka dapat disimpulkan bahwa:

1. Bagian administrasi dapat memantau dan merekapitulasi data presensi pegawai sesuai dengan kubutuhan yang diinginkan.

2. Pegawai yang sedang melakukan dinas luar dikantor sudah bisa melakukan absensi tanpa harus kekantor terlebih dahulu dan beban kerja yang diterima oleh pegawai sedikit berkurang.

3. Dengan adanya koordinat saat melakukan absensi pegawai tidak dapat melakukan kecurangan dikarenakan dapat dipantau oleh bagian administrasi secara langsung.

Berdasarkan kesimpulan di atas, maka penulis merekomendasikan berupa saran-saran sebagai berikut:

1. Sistem informasi ini hanya dibangun berbasis website dan nge-build web ke apk android, sehingga di harapkan ke depannya dapat dikembangkan menjadi lebih baik lagi.

2. Pada penelitian berikutnya, diharapkan agar bisa dikomparasi dengan menggunakan metode lainnya untuk menghasilkan suatu penelitian yang lebih baik.

3. Untuk pengembangan aplikasi selanjutnya, pada proses absensi dinas luar ditambahkan fitur selfie untuk data lampiran absensi dinas luar pegawai.

\section{REFERENCES}

[1] S. R. Aini, Qurotul and Graha, Yuliana Isma and Zuliana, "Penerapan Absensi QRCode Mahasiswa Bimbingan Belajar pada Website berbasis YII Framework," Sisfotenika, vol. 7, no. 2, pp. 207-218, 2017.

[2] B. Setiawan, Eko Budi and Kurniawan, "Perancangan Sistem Absensi Kehadiran Perkuliahan dengan Menggunakan Radio Frequency Identification (RFId)," J. CoreIT J. Has. Penelit. Ilmu Komput. dan Teknol. Inf., vol. 1, no. 2, pp. 4449, 2015

[3] C. A. W. Mulyandi, Rachman and Dini, "Aplikasi Absensi Pegawai Kecamatan Batuceper Tangerang Dalam Meningkatkan Akurasi Informasi,” CCIT J., vol. 7, no. 2, pp. 269-279, 2014.

[4] N. F. Putri, Jashinta Anggriana and Soeliman, "ANALISIS DAN IMPLEMENTASI REPORTING SERVICE PADA APLIKASI ABSENSI PNS MENGGUNAKAN SSRS," InfoTekJar J. Nas. Inform. dan Teknol. Jar., vol. 2, no. 1, pp. 27-32, 2017.

[5] F. Mahdia, Faya and Noviyanto, "Pemanfaatan Google Maps API untuk pembangunan sistem informasi manajemen bantuan logistik pasca bencana alam berbasis mobile web (studi kasus: badan penanggulangan bencana daerah Kota Yogyakarta)," J. Sarj. Tek. Inform., vol. 1, no. 1, pp. 162-171, 2013.

[6] A. Putra, Darma Setiawan and Fauzijah, "Perancangan Aplikasi Presensi Dosen Realtime Dengan Metode Rapid Application Development (RAD) Menggunakan Fingerprint Berbasis Web," J. Inform. J. Pengemb. IT, vol. 3, no. 2, pp. 167-171, 2018.

[7] E. Budiman, "Pemanfaatan Teknologi Location Based Service Dalam Pengembangan Aplikasi Profil Kampus Universitas Mulawarman Berbasis Mobile,” Ilk. J. Ilm., vol. 8, no. 3, pp. 137-144, 2016.

[8] A. Juansyah, "Pembangunan Aplikasi Child Tracker Berbasis Assisted--Global Positioning System (A-Gps) Dengan Platform Android," J. Ilm. Komput. dan Inform., vol. 1, no. 1, pp. 2-3, 2015.

[9] V. Kakunsi, Deddy Ch and Rindengan, Yaulie DY and Tulenan, "Rancang Bangun Web Services pada Aplikasi Presensi di Badan Kepegawaian Daerah Kota Manado," J. Tek. Elektro dan Komput., vol. 2, no. 4, pp. 66-70, 2013.

[10] R. W. Nuryani, Shinta Sindi and Gumilang, Soni Fajar Surya and Witjaksono, "Penerapan Sistem Absensi Berbasis Openerp Pada Cv. huda Jaya Dengan Metode Rapid Application Development," eProceedings Eng., vol. 2, no. $2,2015$.

[11] M. Kustar, "Monitoring Kegiatan Kuliah Kerja Nyata Menggunakan Fitur Location Based Service," J. Sist. Inf. dan Ilmu Komput. Prima (JUSIKOM PRIMA), vol. 1, no. 2, 2018. 